\title{
Casting the Net Wider: Network Approaches to Artefact Variation in Post-Roman Europe
}

\author{
Toby F. Martin ${ }^{1}$ \\ Published online: 11 January 2020 \\ (C) The Author(s) 2020
}

\begin{abstract}
This paper explores the stylistic variability of fifth- and sixth-century brooches in Europe using network visualisations, suggesting an alternative means of study, which for more than a century has been dominated by typology. It is suggested that network methods and related theories offer alternative conceptual models that encourage original ways of exploring material that has otherwise become canonical. Foremost is the proposal that objects of personal adornment like brooches were a means of competitive display through which individuals mediated social relationships within and beyond their immediate communities, and in so doing formed surprisingly far-flung networks. The potential sizes of these networks varied according to their location in Europe, with particularly large distances of up to $1000 \mathrm{~km}$ achieved in Scandinavia and continental Europe. In addition, an overall tendency toward the serial reproduction of particular forms in the mid-sixth century has broader consequences for how we understand the changing nature of social networks in post-Roman Europe.
\end{abstract}

Keywords Archaeology · Networks · Early medieval Europe · Typology

\section{Introduction}

Historically speaking, few classes of object can claim a higher level of influence over the archaeology of their periods than the elaborate bow brooches of the fifth to seventh centuries. Their distinctive regional styles and apparent transmissions around Europe have given rise to more than a century of debate concerning migration and ethnicity, exemplified by the now controversial but still casually used labels of 'Frankish

Electronic supplementary material The online version of this article (https://doi.org/10.1007/s10816-01909441-x) contains supplementary material, which is available to authorized users.

Toby F. Martin

toby.martin@conted.ox.ac.uk

1 Department for Continuing Education, University of Oxford, Rewley House 1 Wellington Square, Oxford OX1 2JA, UK 
brooches', 'Thuringian brooches', 'Slavic brooches' and so on. The ubiquity of such ethnic terminology is surely related to the dominance of typology in the scholarship of these artefacts, thanks to its emphasis on grouping and delineation. Brooches have become exemplars of the typological method due to the geographical and chronological patterning that arises from their particularly complex stylistic variation. A mass of predominantly typological literature stretches back to the late nineteenth century, yet for some decades, there has been a palpable ambivalence toward the typological method due to an impasse in debates over the relative subjectivity of the method (e.g. Adams and Adams 1991) as well as scepticism toward the idea that typology will ever provide a definitive means of tracing ethnic identity (Hakenbeck 2007; Gauß 2009; Theune 2014), leading to polarised opinions that have made it harder to traverse the divide. Despite this apparent malaise, thanks to its practical utility and the tenacity of convention, in all European scholarly traditions, typology endures as the dominant framework through which artefacts are encountered, but perhaps brooches more so than most. As a result, rather than being synthesised into wider understandings of post-Roman Europe, brooches have tended to become relegated to typo-chronological studies in which the outlook is deeply erudite but not always conceptually innovative.

This paper suggests that network methods present an alternative to typological classification, bringing with them new research questions that help to put brooches back into an integrated research framework. Two factors may aid this integration: widening the scale of study and turning our attention from the delineation of groups to the understanding of relationships.

In terms of scale, as typological knowledge has increased, specialists have tended to look at increasingly smaller regions and periods, losing sight of the bigger picture (Martin 2019). There are exceptions with a wider view (Gauß 2009), but even the largest of recent surveys have tended to adhere to the traditional divisions of the material into its Continental (Koch 1998), Scandinavian (Røstad 2016) and British (Martin 2015) components. In this paper, four major groups of brooches from fifth- to sixth-century Scandinavia, Britain and continental Europe are compared for the first time on equal terms. These broader scales immediately transcend questions to do with ethnic identity because they exceed any reasonably conceived scale over which such identities might have operated, and this has been achievable only through transcending traditional typological methods and turning toward network visualisations. Similarly, by concentrating on the relationships between objects rather than their delineation into groups, network methods prompt questions less concerned with the identification of groups localised in time and space, and focus instead on the illustration and comprehension of relationships and connectivity (see Mills 2017; Mol 2007; Van Oyen 2016a, $2016 \mathrm{~b}$ ). The result of this double change in scale and method represents a conceptual shift away from the reconstruction of bounded groups (however defined), and toward the characterisation of relational structures.

Two contemporary concerns inspire shifting focus away from delineation and regionality and onto relationality and scale. The first is the continuing urgency for postcolonial approaches in archaeology, which suggest that the definition and naming of groups of material and its attendant cultural groups is a form of colonialism that attempts to control the complexity of the past by ordering its submission to disciplinary authority in the present (see Van Oyen 2013, 86-7). The second is a rising need to accommodate and understand the 'global middle ages', in which the theme of 
connectivity is also dominant (Holmes and Standen 2018, 2). Scaling up research on brooches to a continental level represents a preparatory step in the direction of understanding post-Roman Europe in a global context.

\section{Typology as a Reductive Method}

European brooches in the fifth and sixth centuries $\mathrm{AD}$ all have various regional affinities, and these affinities have in the past been equated with ethnic groups. However, a glance at the distributions of some of the most familiar types (Fig. 1) indicates something far messier. For instance, brooches with a semi-circular headplate and a narrow foot, usually attributed to the Franks and the Alamanni (Kühn 1965; Koch 1998), have a distribution that centres on the historically attested Frankish/Alamannic region of western France and southwest Germany, but expands far beyond it. Something similar can be said for the Thuringian brooches of Central Germany, although the historical region itself is more debatable (Neumeister 2014). The distribution of the socalled Langobard brooches with a semi-circular headplate and oval footplate again broadly aligns with the historical territories in Central Europe and later Italy (Fuchs and Werner 1950), but it could hardly be considered discrete, and overlaps substantially with the supposedly Frankish/Alamannic brooches. Meanwhile, the so-called Slavic brooches (Werner 1950) bear a more obvious relationship to the former Iron Curtain than they do to the historically recorded territories of the Slavs (Curta 2006).

The basic picture provided by coarse typological classification is therefore fuzzy. The types have distinctive regional characters, but they are by no means mutually exclusive. Brooches share both highly localised similarities, as well as correspondences over distances far in excess of $1000 \mathrm{~km}$. As objects generally worn by women, nowhere do they indicate discrete blocks of homogeneous feminine dress, and because of that, we might suggest a degree of internal competition, perhaps based on the demonstration of links within and beyond the immediate community. Something similar can be said for understandings of Late Antique ethnic identities drawn from the historical literature, which have long rejected primordialist interpretations and instead emphasised the instrumental use of fluid ethnicities (e.g. Wenskus 1961; Pohl 2002). Thus, traditional approaches to both artefacts and identity have been reductionist. They have abridged complex spatial distributions and complex identities into simplified and circumscribed taxonomies (Effros 2004; Hakenbeck 2007; Halsall 2010, 93-106). While most historians and archaeologists working with ethnicity have shrugged these attitudes, they sometimes persist among studies of objects.

In terms of the material at hand, the most powerfully reductive force at work has been methodological, in that the reductive impetus lies in typology itself, a method that necessarily reduces complex variation into neatly bounded categories. Accordingly, there is a predisposition for the outcomes of typological work to involve discussion concerned with group identities, variously defined since the nineteenth century to the present day, including recent constructivist takes on ethnicity that emphasise the role of material culture in the production of such identities in the first place (Martin 2015; Røstad 2016). Something similar applies of course to studies that draw lines between a typological group of objects and any social group defined by identity or social role, be that concerned with gender, age or social status (Stoodley 1999; Kristoffersen 2000, 

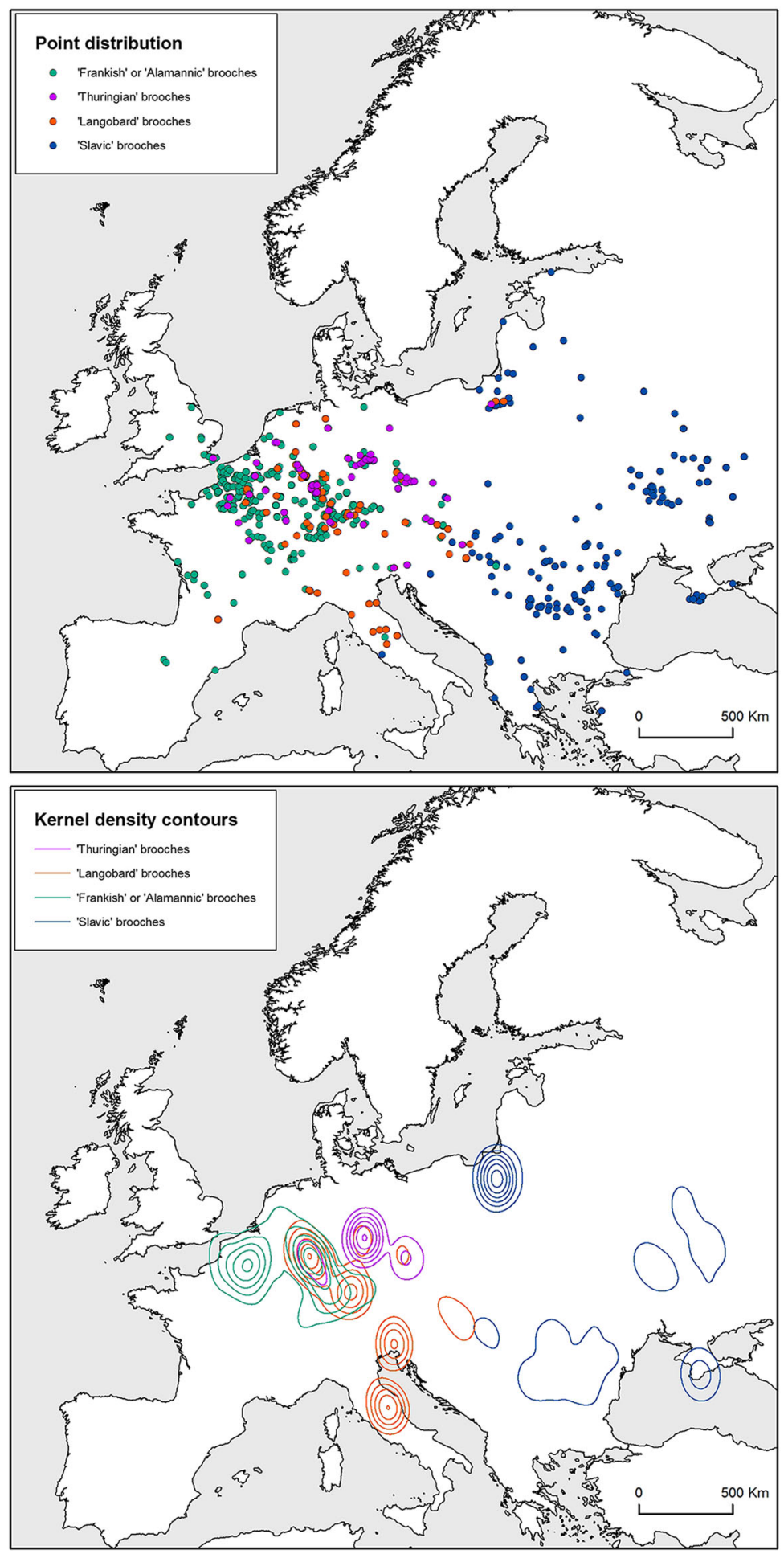
Fig. 1 The distribution and kernel density of brooches traditionally assigned to the Franks and Alamanni (i.e. brooches with a semi-circular headplate and narrow foot, $n=1184$ ), Langobards (i.e. brooches with a semicircular headplate and oval foot, $n=242$ ), Thuringians (i.e. brooches with 'pincer' or bird-headed headplates, $n=119$ ) and Slavs (i.e. Werner's types I and II, $n=340$ ). Distributions derived from data extracted from the Early Medieval Brooches of Europe Database (EMBED, see Martin 2019)

2004; Martin 2015). That is not to say that such approaches are any less valuable, and there is much valuable work still to do in this vein. The critique is that although typology remains a practical and useful tool, its dominance in certain subjects tends to drive research down particular interpretative pathways.

Another consequence of the typological method is that unique artefacts that do not fit into prescribed groups tend to be silenced so that neat typological schemes can be devised at the expense of openly interrogating the flow of stylistic variation, despite the long-observed observation that these brooches entailed 'composite design' (e.g. Leigh 1980; Hines 1997). 'Composite design' entails that each brooch was conceived as a number of fields such as the headplate, bow and footplate. Broadly speaking, composite design suggests that choices were made for the form or decoration of each field by selecting an appropriate model from a repertoire of elements or inventing a new one. The term 'appropriate' is important because although this schema fosters heterogeneity, some combinations were clearly more acceptable or pleasing than others. In other words, there was an aesthetic grammar behind the designs of brooches, albeit a malleable one (Dickinson 1991; Martin 2015, 14-16). A detailed version of this kind of thinking has recently been described in detail by Pedersen and Kristoffersen (2018), in which the composite design of a single brooch is suggested to have been the product of more than one craftsperson working on a single object. It may be the case that our Frankish, Langobard, Thuringian and Slavic brooches may or may not have been owned in their majority by individuals who called themselves Franks, Langobards, Thuringians or Slavs, but the objects themselves were essentially the most common combinations of particular sets of components found within a particular geographical range. Typology alone is an inadequate tool to tackle this kind of variation. Its necessarily reductive procedures have not only abridged the complexity of these objects, but they have also reduced our view of the people who made and wore them.

\section{Theoretical Background}

A methodological shift is therefore necessary to experiment with something other than the repetitious definition of ever smaller, ever more precisely defined and ever more bounded groups, so that we can use brooches to investigate aspects of the past that do not revolve around the grouping of people. Various strands in contemporary thought advocate against abrupt distinctions between the social and material worlds (Latour 2005; Coole and Frost 2010; Ingold 2012). Indeed, rejecting anthropocentrism, or the primacy of people over objects, is a major feature of this current inclination (Thomas 2015). Accordingly, the pursuit of a society behind the objects, or an ethnic group signified by a group of objects, becomes chimerical, because it is objects themselves and their interactions with people that help constitute that society. Furthermore, Gosden and Malfouris (2015) have argued that it is not just the relationships between people that are in constant flow, but if one switches to an object-centric timescale, objects themselves are in a constant state of 
'becoming'. Although Gosden and Malfouris refer specifically to the physical transformation, decay or recycling of materials, their ideas might be used gainfully to reflect upon the relationships between objects in a typological series. With knowledge of a typological sequence, one does not envision each example as an unambiguous member of a discrete group but as just one cog in an 'abstract machine', an emergent system of self-organisation territorialised by archaeologists into a 'type series' (Deleuze and Guatarri 1987, 510-14). For makers of artefacts, the prototype or terminal descendant in such a series is neither of these things; both are simply exemplars of a style. Like the perpetually transforming materials of Gosden and Malfouris, members of a type series join a flow of related objects that are in a continuous state of becoming. There is no such thing as the prototypical 'cruciform' or 'square-headed' brooch. Not only are these things blatant scholarly edifices, but they also describe abstract ranges of variation-Platonic archetypes - rather than actual entities (see also Van Oyen 2015).

This slippery state of perpetual metamorphosis provokes questions about the intentionality behind artefact variation. If formal or stylistic variation is an emergent property arising from interactions between makers and the pre-existing objects that surround them (Thomas 2015, 1289, citing Ingold 2012), it makes more sense to pursue the consequences of typological patterning (e.g. relationships drawn between people wearing similar objects) rather than its supposed causes (e.g. group identities). Pre-existing relationships between people expressed in type series are not necessarily chimerical, but they are at least partly constituted by the objects involved in that relationship. Once we have accepted that both objects and people are not atomistic but formed by multiplicities of practices and motivations, a postcolonial 'anti-categorical' approach becomes attractive, wherein objects are not envisioned as indivisible monoliths (i.e. a type, a sub-type) created by single cultural variables with single social outcomes (i.e. ethnicity, status), but instead as sets of differentially structured relationships that provide different potentials for action. One productive analysis from this starting point would be to characterise the structures of those relationships (Martin 2015, 87-9; Astrid Van Oyen 2012, 2013, 2016c). The method suggested in this article provides an empirical and analytical means of examining these relationships and visualising the 'relational constellations' described by Van Oyen (2016). It represents an attempt to capture a picture of flow and in so doing rediscover something of the relationships between people and objects.

\section{The Square-Headed Brooches of Europe: Data and Methods for Network Analyses}

The alternative to traditional typological analysis suggested here is based on the idea that stylistic links between objects can be visualised as a network, no less abstract than a typology, but conceptually different on at least two counts. Firstly, network methods are less reductive and permit greater complexity because every object can be represented in a visualisation, and at least some of their multiple characteristics can be expressed. Secondly, as will be demonstrated, network methods can be used to illustrate structures — or perhaps 'rhythms' — of variation. While at certain times and places objects might be produced with a higher degree of conservatism, at others there will be explosions of creativity and variation. These are the new metrics that might take the place of typological groups, and the identification of currents of creativity and 
conventionality provides unorthodox but useful and interpretable information, that may, for instance, be linked to competition, resistance and compliance and more other sophisticated aspects of group dynamics than the declaration of a group based on a particular type of object can articulate.

This paper will illustrate these ideas with a well-studied series of brooches that share the same form (square headplates and diamond-shaped footplates) and are therefore appropriate objects for comparison. They also happen to be the 'deluxe' brooches of the fifth and sixth centuries, being the primary vehicles for the animal art that typifies the period ('Salin's Style I'), reaching relatively large sizes, and frequently cast in precious metals. Their regional variants have specific names: great square-headed brooches from eastern England; Kentish square-headed brooches from either side of the Channel; continental square-headed brooches from Germany and France (with lesser numbers from the Low Countries, Central Europe and Italy); and the square-headed variants of the Scandinavian relief brooches (Fig. 2). For the sake of simplicity, these regional groups will be referred to as the English, Kentish, Continental and Scandinavian

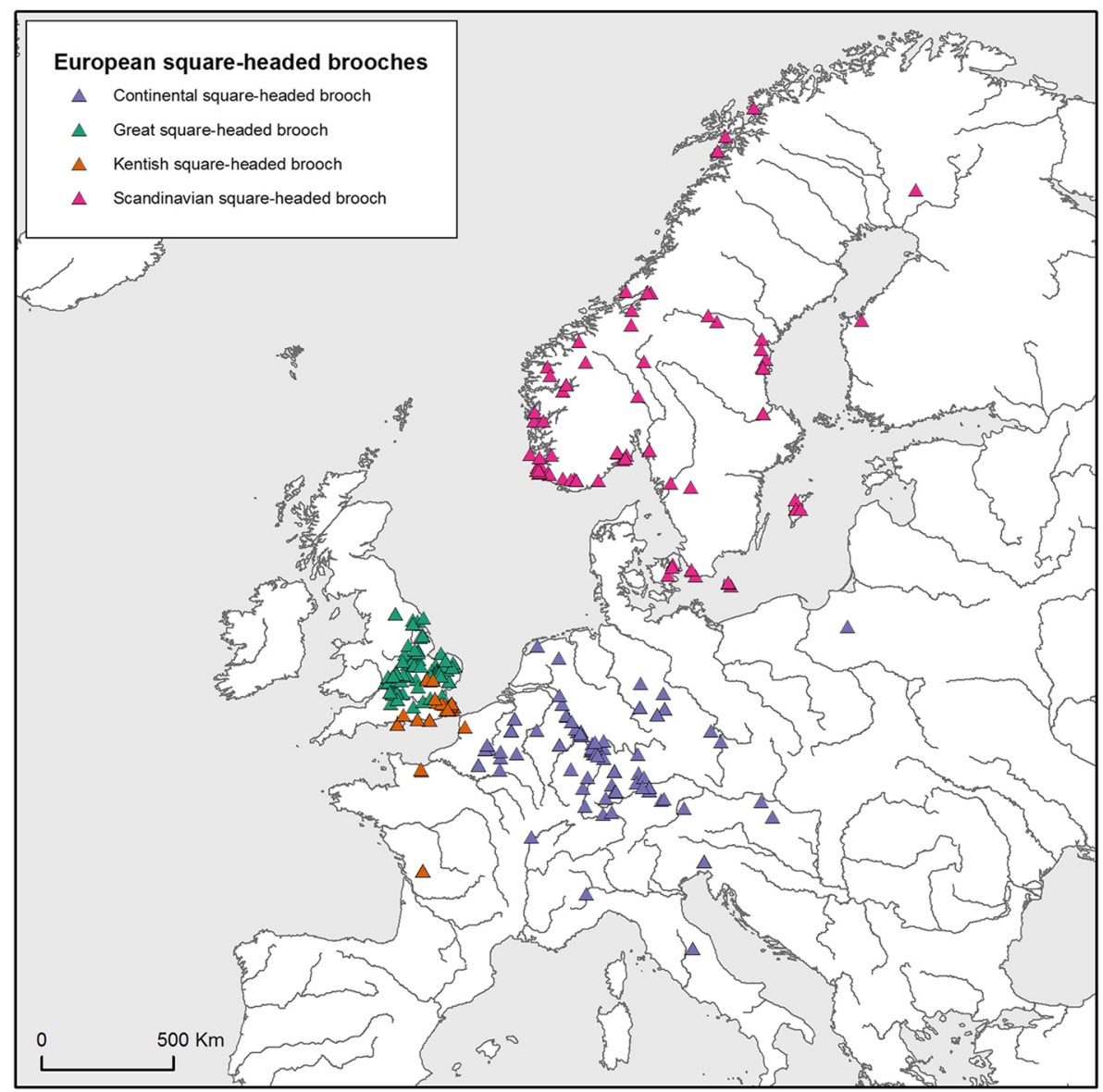

Fig. 2 The distribution of the English, Kentish, Scandinavian and Continental series of square-headed brooches, showing only the 408 complete examples outlined in Table 1 


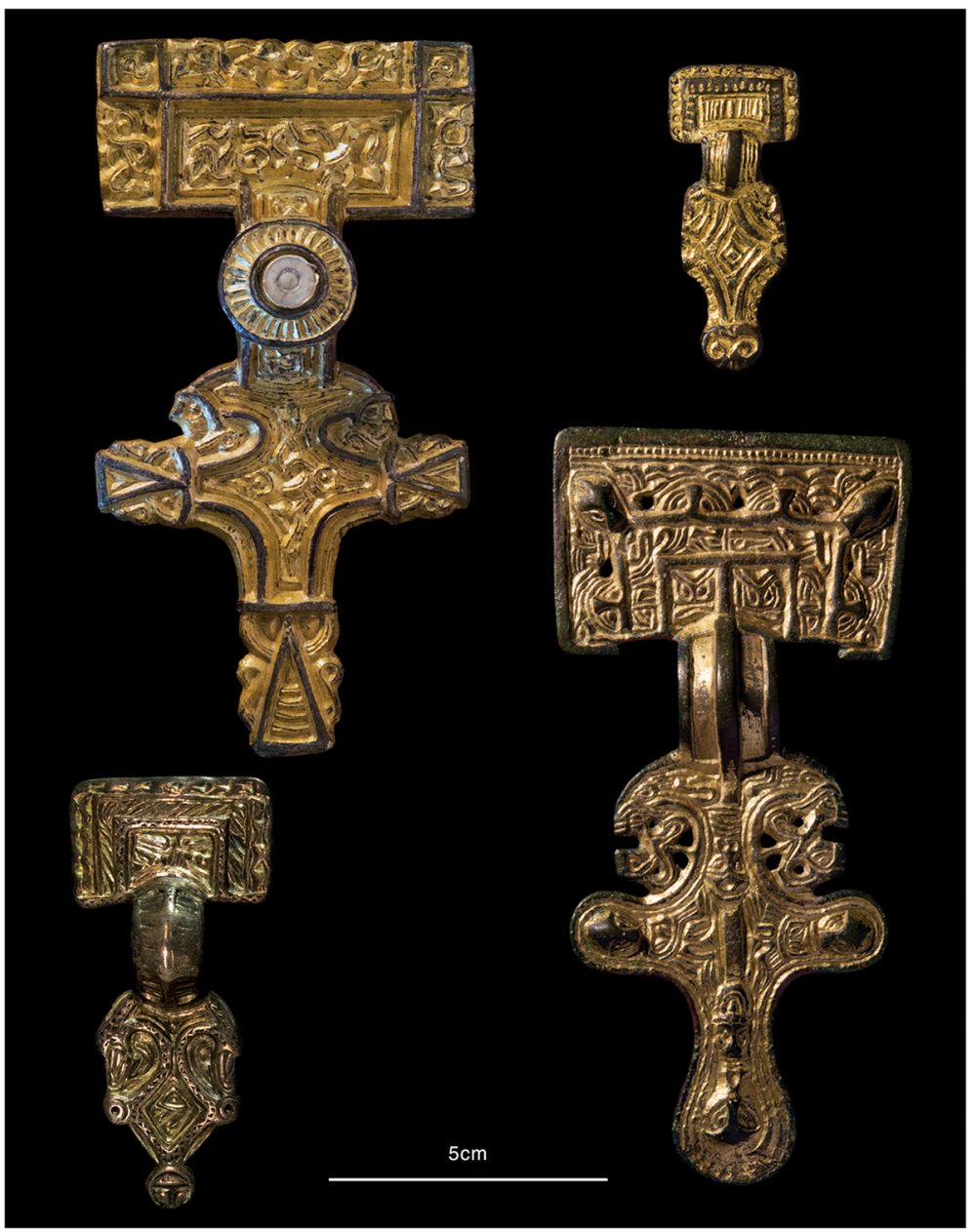

Fig. 3 Examples from the four series of European square-headed brooches. Clockwise, from top left: Scandinavian square-headed brooch from Syre, Rogaland, Norway (Stavanger Museum, S.9269); Kentish square-headed brooch from Chatham Lines, Kent, England (Ashmolean Museum, AN 1991.165); great square-headed (English) brooch from Brighthampton, Oxfordshire, England (Ashmolean Museum AN 1966.121); Continental square-headed brooch from Anderlecht, Brussels, Belgium (Bruxelles Musées royaux d'Art et d'Histoire, B000956-033). All photos by T. Martin

square-headed brooches (Fig. 3). ${ }^{1}$ Only complete as opposed to fragmentary brooches were included, as well as only one of every identical pair from the same grave context, giving a total of 408 unique items. Table 1 summarises the catalogues that form the basis of this paper, which are included in full in the electronic supplementary material (Online Resource 1).

\footnotetext{
${ }^{1}$ The 'Jutlandic brooch group' (Haseloff 1981, 22-3) is excluded from this study with the exceptions of the examples from Tveitane (Norway) and Åker (Sweden), which can also be viewed as integral to the Scandinavian square-headed brooch series.
} 
Table 1 Corpora of square-headed brooches used in the analyses

\begin{tabular}{|c|c|c|}
\hline Regional type & Quantity & Catalogues used \\
\hline Great square-headed brooches & 148 & Hines 1997 \\
\hline Kentish square-headed brooches & 76 & $\begin{array}{l}\text { Leigh 1980, with minor additions from } \\
\text { Hines } 1997 \text { and Koch } 1998\end{array}$ \\
\hline Continental square-headed brooches & 121 & $\begin{array}{l}\text { Haseloff 1981; Koch 1998; Kühn 1965, 1974; } \\
\text { 1981; Leigh } 1980\end{array}$ \\
\hline Square-headed Scandinavian relief brooches & 85 & $\begin{array}{l}\text { Sjøvold } 1997 \text { with a minor addition from } \\
\text { Reichstein } 1997\end{array}$ \\
\hline
\end{tabular}

In the networks presented below, each individual brooch is conceived as a 'node', and each stylistic similarity with another item is conceived as connection, or an 'edge', whose 'strength' varies according to the measure of that similarity (for terminology see Brughmans 2012 and Collar et al. 2015). In order to perform such an analysis, each object was divided into a number of fields supplied by the components of the overall design: the headplate outer frame, inner frame and central panel; the bow; the lappets; the lobes; the foot; and the terminal, as illustrated in Fig. 4. Because their form defines these fields, they will be referred to as 'formal components'. Not all examples, even if they were complete, necessarily possessed all eight of these formal components, but this is not important, as it permits only minor asymmetries in the data. This division permits a maximum number of eight possible counts on which any number of brooches can be compared, providing a score between one and eight for the strength of the relationship between any two brooches. In other words, the strength of each 'edge' can vary between one and eight, where eight is the strongest and will be coloured darkest in the following diagrams. With this basic structure defined, the stylistic varieties of each formal component were classified according to their design, based on the presence of a particular 'motif'. While there is not room here to detail every motif, a small number of illustrative examples are given in Fig. 4, their quantities are summarised in Table 2 and the classificatory data is included in full in the electronic supplementary material (Online Resource 1). Figure 5 illustrates the range of variation within a very small sample of the motif classifications. A total of 288 motifs were designated across all eight formal components, each of which occurred on at least two brooches in the sample of 408 complete and unique items. As can be seen, some formal components exhibited more variation than others, with the central panel of the headplates being particularly open to experimentation, and lobes and terminals being decorated using a smaller repertoire of motifs.

Motifs were designated according to subjective judgements regarding their copying, such as an outer headplate border of thirteen inverted human masks, or a central panel containing a particular configuration of animal and human components. If the essential idea of the motif was shared, then a classification was made. Exact replication was not deemed a necessary criterion, as these are far too rare to build any kind of broad picture. As such, the rationale lies somewhere between what Hines (1997, 7) has called 'equivalent' and 'related' motifs. As can be seen in Fig. 5, although the idea behind each motif remains constant, its method of execution varies. Such variation might result from long chains of copying, or perhaps memorised or even verbally communicated 


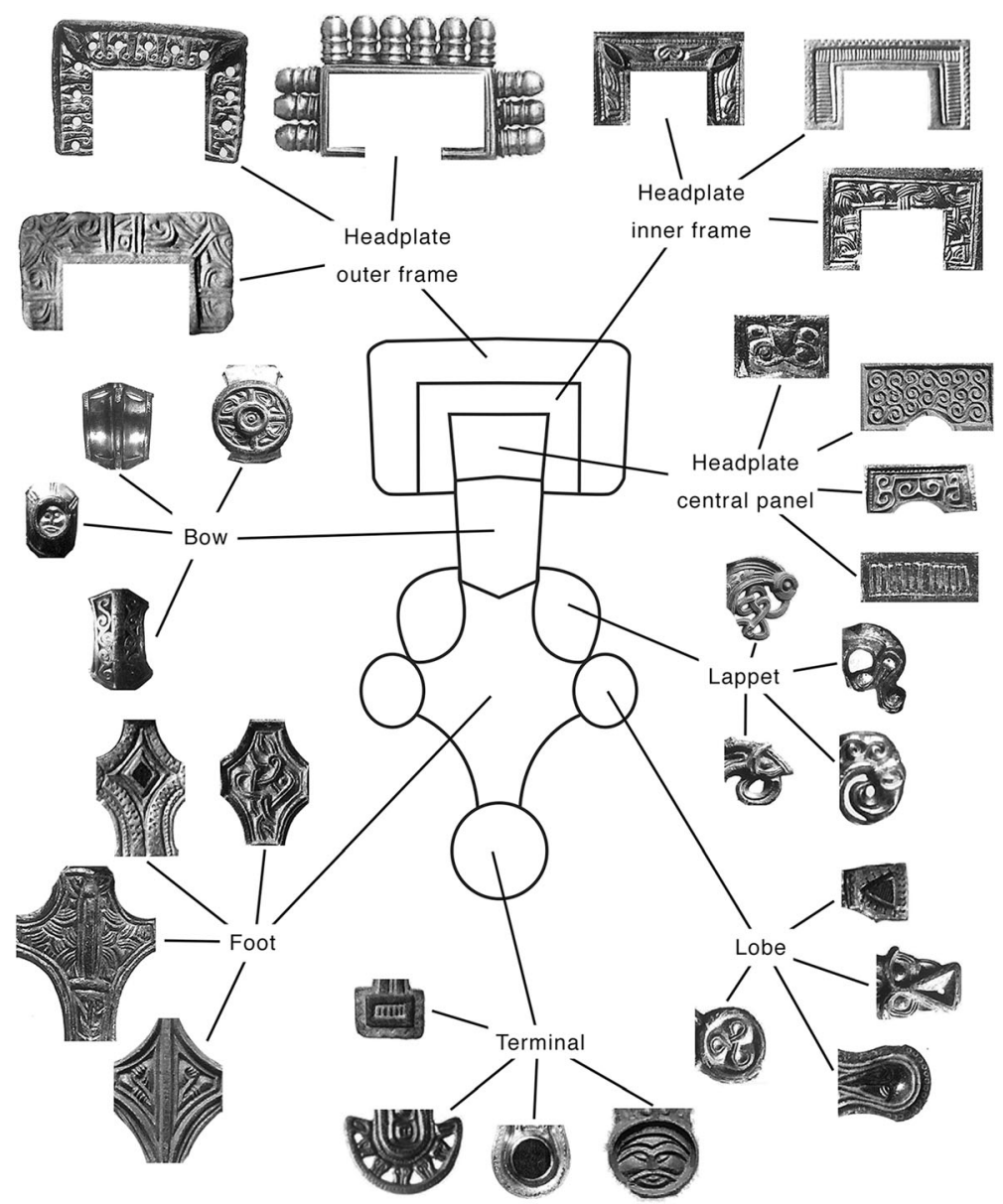

Fig. 4 The eight formal components of square-headed brooches (outer and inner headplate frame, central panel of headplate, bow, lappet, lobe, foot and terminal) and small number of examples of the classified motifs drawn from all four European series. Images extracted and adjusted from Koch 1998; Sjøvold 1993; and Hines 1997

designs rather than direct transcriptions from one object to another. Accordingly, there is no way of calculating how many steps or intermediate artefacts there were between particular examples of a motif. Each link probably signifies repeated and prevalent collective acts of reference or citation. It is important to state that the precise classificatory scheme and the fineness of its resolution are not necessarily critical considerations here, as similar results would be generated with most variations. Reassuringly, the major results presented below chime with previous independent observations made of structural patterns within these four series individually (Hines 1997; Leigh 1980; Sjøvold 1993; Haseloff 1981; Kristoffersen 2000; Røstad 2016).

On a conceptual level, the method is of course still typological. The implementation of any network analysis based on categorical data entails classificatory reasoning at some level. While it is true that the classification of motifs certainly reduces the infinite complexity of the objects, here, it is at a sub-object level, which offers a meaningful 
distinction compared with traditional typological methods, which generalise sub-object characteristics into super-object classes. In other words, the interpretative potential of artefact variation is limited when the fluid characteristics that make up any object are abbreviated into single categories. The network methods explored here pursue less abbreviation than traditional typology.

\section{Chronology}

Difficulties aligning the chronologies of the four regional types illustrate the need for larger scale approaches as well as the challenges such approaches present. While some confidence can be placed in the relative chronologies of the English, Scandinavian and Continental series (Table 3), the absolute dates should be viewed with considerable caution. These chronologies are all based on a mixture of typology and the seriation of grave assemblages, with a small number of coin dates from the Continental series. The most reliable is the relative chronology of the Scandinavian series, which has seen some adjustments since Nissen Meyer's work of 1934 (Bakka 1973; Straume 1987; Kristoffersen 1999, 2000). Kristoffersen's phases D1, D2a and D2b are used here supplemented by Røstad's (2016) recent classifications. Hines' (1997) work on the relative chronology of the English series remains persuasive, and his phases 1, 2a, 2b and 3 are directly lifted from that account. The Continental series has seen only fragmented treatment since Nissen Fett's (née Meyer 1941) account, and there has been a tendency for dating individual items rather than placing them in any relative phasing system. The relative phases used here have been created especially for this study, by extrapolating contemporary items from the absolute dates given by Haseloff (1981) and Koch (1998). Although much of its detail requires considerable work, it follows the generally agreed development of Salin's Style I from its earliest phases (phase I), through its development and geometricisation (phase II), to its absence (phase III). ${ }^{2}$ Brugmann's work on the Kentish series chronology has not been used here as it has only been presented partially (most recently in Parfitt and Anderson 2012, 78), and despite Leigh's (1980) account, which is more based on specific aspects of manufacture than style, there is no overall typology for these brooches.

\footnotetext{
${ }^{2}$ In more detail, phase I includes brooches belonging to Haseloff's großen Tier and Kircheim unter Teck groups, and individually dated examples of brooches of various categories from Eltville, Mühlhofen, Flomborn, Nordendorf and Beuchte (Haseloff 1981, 361-2, 417, 432, 439, 444, 473, 504). Phase II1 consists of brooches belonging to typ Langweid, originally defined by Kühn (1965, 340-6), but refined by Haseloff and Koch, as well as independently dated brooches from Großkuchen (Koch 1998, 334; Haseloff 1981, 363, 529), Charnay-lès-Chalons, Monceau and Schwarzrheinfdorf (Koch 1998, 357, 359). Phase II2 includes typ Cividale, defined by Kühn (1965, 314-19) and restated by Koch (1998, 339), typ Rittersdorf, defined by Kühn $(1965,329-37)$ and much refined by Haseloff $(1981,517)$ and Koch $(1998,354)$, Haseloff's brooches with geometricised animal ornament (Haseloff 1981, 524, see also Koch 1998, 335), as well as individually dated brooches from Mühlhausen, Güdingen, Schaftstädt, Anderlecht and Öbermollern (Haseloff 1981, 500, 505, 527, 529; Koch 1998, 362). Finally, phase III consists of brooches of typen Caulaincourt and Crailsheim, both originally defined by Kühn $(1965,337-40 ; 1974,1176-8)$, the former of which have has been dated by Koch $(1998,347)$, while the latter is seen as contemporary, thanks to its very close typological relationship. Perhaps surprisingly, the only notable disagreement between Koch and Haseloff lies in the dating of typ Langweid, which Haseloff places in the first half of the sixth century, but Koch more conservatively places only very generally across the whole century. Koch's reservations are taken into account here by placing typ Langweid in phase II1 rather than I.
} 
Table 2 Quantification of the classifications of formal components

\begin{tabular}{lcc}
\hline Formal component type & Types & Non-unique types \\
\hline Headplate outer frame & 44 & 37 \\
Headplate inner frame & 20 & 20 \\
Headplate central panel & 71 & 60 \\
Bow & 44 & 43 \\
Lappets & 32 & 32 \\
Lobes & 21 & 19 \\
Foot & 53 & 47 \\
Terminal & 30 & 30 \\
Total & 315 & 288 \\
\hline
\end{tabular}

The absolute dates of these four series are less reliable, and at this stage, it is not possible to synchronise them with much confidence. As such, the dates given in Table 2 merely summarise the existing state of knowledge rather than present a coherent scheme. The biggest difficulty is that recent work on Norwegian material has pushed the earliest squareheaded brooches back into the first half of the fifth century, pulling the later phases back with it (Kristoffersen and Magnus 2010, 94; Fredriksen et al. 2014, 2). The significant gap that now lies between the earliest Kentish, English and Continental square-headed brooches and their Scandinavian equivalents is problematic. Although the Scandinavian series may well have commenced a little earlier than the others, a half-century seems unnecessary. Indeed, the four series are likely to have been broadly contemporary, and the results of the analysis presented here may well have chronological implications that could be taken forward elsewhere. Work is sorely needed in this area, but for the time being, it is only necessary to observe that at least three of the four series have obvious earlier and later phases, with middle phases that can be subdivided with less confidence. More detail on the chronology of individual examples is given in Online Resource 1.

\section{Analysis: Artefact Variation Visualised as Networks}

Figure 6 illustrates a network visualisation constructed from these classifications for all four regional series. ${ }^{3}$ The network is arranged using a 'backbone layout': a commonly used method for untangling so-called 'hairball' networks wherein a very high number of edges link a small number of nodes, such as this one in which 49,000 edges link just over 400 brooches sharing between one and eight attributes. The backbone layout in Fig. 6 reduces that complexity by removing edges with a strength of two or less (i.e. it displays only ties between brooches that share three of more attributes), and has arranged the nodes in a graph according to a clustering algorithm (taking into account both the strength of a tie and the density of the graph around it, see Nocaj et al. 2015).

\footnotetext{
${ }^{3}$ Brooch attribute data were converted into network data using UCINET 6.586. All layouts were constructed using Visone 2.17. 

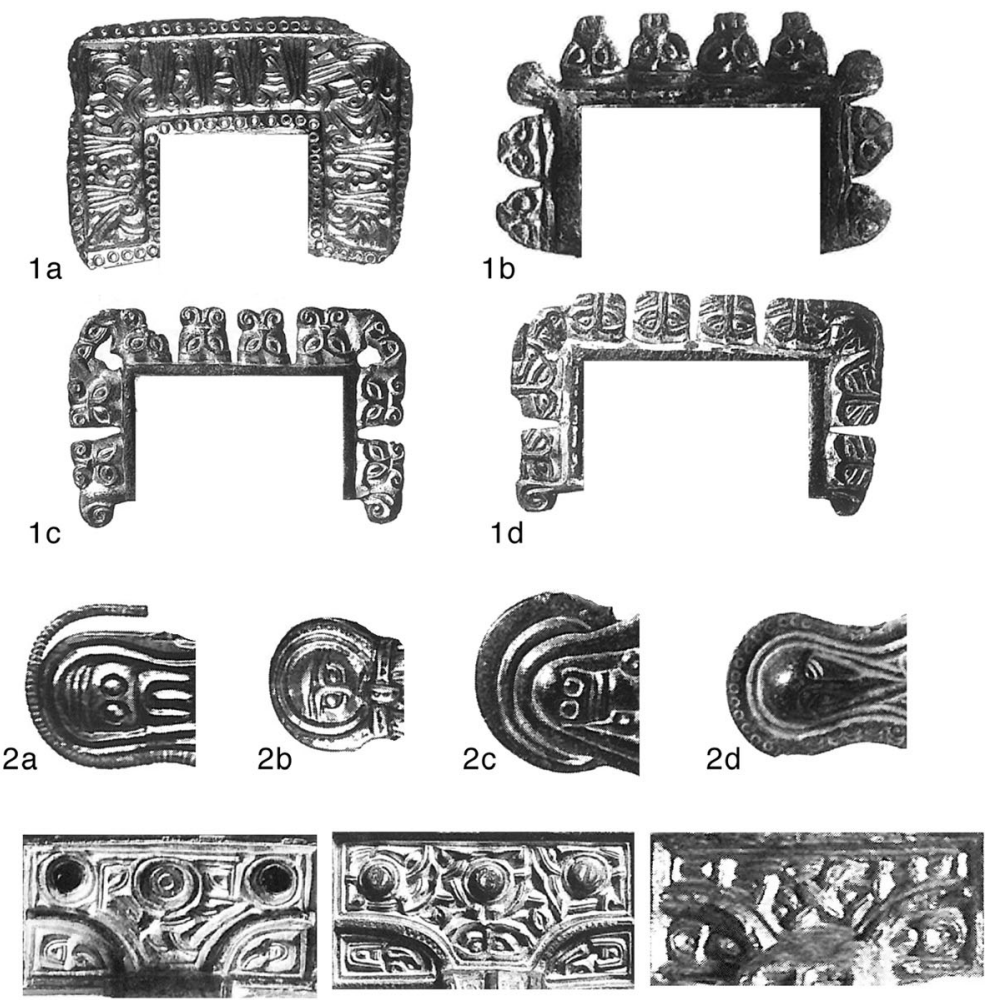

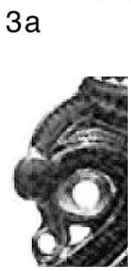

$4 a$

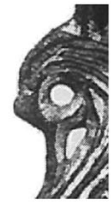

$4 b$
$3 b$

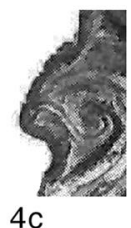

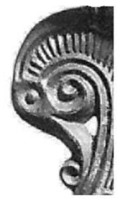

$4 d$

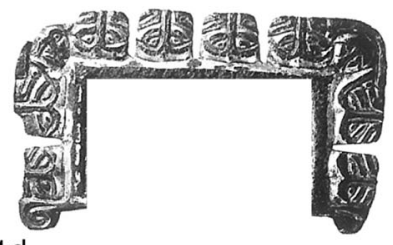

$1 d$

Fig. 5 Examples of motif categorisations. 1. Headplate outer frames of type Masks06: 1a. Thornborough, England; 1b. Barrington A (Edix Hill), England; 1c. Linton Heath, England; 1d. Tuddenham St Mary, England; 2. Lobes of type Mask01: 2a. Alfriston, England; 2b. Chessell Down, England; 2c. Londesborough, England; 2d. Berinsfield, England; 3. Central panels of type Beasts15: 3a. Brunflo misionhus, Sweden; 3b. Hade, Sweden; 3c. Husvegg, Norway; 4. Lappets of type Profile03: 4a. Charnay-lès-Chalons, France; 4b. Bidford-on-Avon, England; 4c. Vik (Grimstad), Norway; 4d. Hole, Norway; 4e. Faversham (King's Field), England; 4f. Gotland, Sweden; 4g. Testona, Italy. See Online Resource 1 for details on motif type names, images extracted and adjusted from Kühn 1974; Koch 1998; Sjøvold 1993; and Hines 1997. Not to scale

The most striking aspect of the resultant network is the lack of separation between the Scandinavian and Continental series, and the peripheral location of the English and Kentish series, which, despite being found in closer proximity, demonstrate greater divergence in terms of their stylistic repertoires. This echoes previous suggestions that a number of the Continental series were copies of Scandinavian models or even genuine imports (Haseloff 1981, 285-8). The lack of obvious distinction between the Continental and Scandinavia series in the network has also to do with the fact that both series 
Table 3 Summary of chronologies

\begin{tabular}{|c|c|c|c|}
\hline Type & Phase & $\begin{array}{l}\text { Estimated } \\
\text { absolute dates }\end{array}$ & Based on \\
\hline \multirow{4}{*}{$\begin{array}{l}\text { English square-headed } \\
\text { brooches }\end{array}$} & 1 & $500-520$ & \multirow[t]{4}{*}{ Hines 1997, 226-32 } \\
\hline & $2 \mathrm{a}$ & $510-550$ & \\
\hline & $2 b$ & $510-550$ & \\
\hline & 3 & $525-570$ & \\
\hline \multirow{3}{*}{$\begin{array}{l}\text { Scandinavian } \\
\text { square-headed brooches }\end{array}$} & D1 & $400-450$ & \multirow{3}{*}{$\begin{array}{l}\text { Kristoffersen and Magnus 2010, 94; } \\
\text { Fedriksen et al. 2014, } 2\end{array}$} \\
\hline & $\mathrm{D} 2 \mathrm{a}$ & $450-500$ & \\
\hline & $\mathrm{D} 2 \mathrm{~b}$ & $500-550$ & \\
\hline \multirow[t]{4}{*}{$\begin{array}{l}\text { Continental } \\
\text { square-headed brooches }\end{array}$} & I & $500-550$ & $\begin{array}{l}\text { Haseloff 1981, 324-5, 417, 432, } \\
\quad 439,444,473,504\end{array}$ \\
\hline & II1 & $525-575$ & $\begin{array}{l}\text { Haseloff 1981, 362, 529; Koch 1998, } \\
\quad 334,356,359\end{array}$ \\
\hline & II 2 & $550-580$ & $\begin{array}{l}\text { Haseloff } 1981,500,505,517,524 \\
\text { 527, 529; Koch 1998, 335, } 339\end{array}$ \\
\hline & III & $570-630$ & Koch 1998, 344-7 \\
\hline $\begin{array}{l}\text { Kentish square-headed } \\
\text { brooches }\end{array}$ & $\begin{array}{l}\text { No phase } \\
\text { distinction }\end{array}$ & c. $475-550 / 60$ & Parfitt and Brugmann 1997, 99-100 \\
\hline
\end{tabular}

are less strongly internally linked, or more heterogeneous than the English and Kentish series. From Fig. 6, one might also judge the Kentish series to be intermediate between the Continental/Scandinavian items and many members of the English series, which has been noted previously (Hines 1997, 227-9). This network also demonstrates, however, that interactions between these series never passed along just one dominant pathway, but that there are complex similarities between all four of the series, sometimes in unexpected places. The overall outcome of the network visualisation is that even if a brooch appears in its general characteristics to be quite clearly of a Scandinavian, English, Kentish or Continental tradition, it may in fact share more of its motifs with items from other regional traditions. This is a benefit not only of network methods, but also of a much broader scale of analysis than has previously been attempted. However, it is important not to confuse the image in Fig. 6 with a conventional typology: it does not purport to show groups, but relationships between individual items. In so doing, it emphasises the artificiality of our traditionally received typological classifications.

Nevertheless, it is still important to note that the Kentish and English series are much more closely interrelated or internally consistent. One reason for this may be because they are dispersed over considerably smaller areas. Measured approximately, and excluding outliers, the Kentish series covers an area of 50,000 $\mathrm{km}^{2}$ and the English series $71,000 \mathrm{~km}^{2}$. On the other hand, the Continental series covers $700,000 \mathrm{~km}^{2}$ and the Scandinavian series $1,415,000 \mathrm{~km}^{2}{ }^{4}$ Although this certainly raises questions about sample size relative to geographical area and the relative quantities of these brooches in circulation during the fifth and sixth centuries, this may also be a reflection of the more

\footnotetext{
${ }^{4}$ These areas have been approximated from the distributions in Fig. 2.
} 
intensive copying of motifs, or combinations of motifs, with greater ease over shorter distances. The Kentish and English series of brooches might therefore be seen to contain a smaller number of more specific citations, perhaps showing more frequent and intensively exercised contact between non-local groups. In other words, these results can help us to think about past concepts of scale (cf. Van Oyen 2012).

Besides the relationships between the four conventional series, Fig. 6 also shows considerable structural variation. Around the centre of the network, there are large groups of loosely related items with the strengths of their edges being between three and five. Around the edges, showing relatively few relationships with the rest of the series, there are a number of extremely homogenous clusters with between six and eight motifs shared between brooches. These clusters are most clearly analysed by splitting the network into its four components.

Figure 7 shows the English, Kentish, Scandinavian and Continental series separated into individual networks and distinguished according to their relative chronologies (with the exception of the Kentish series which has no reliable internal chronology, see above), based on exactly the same data, and using the same backbone layouts. The

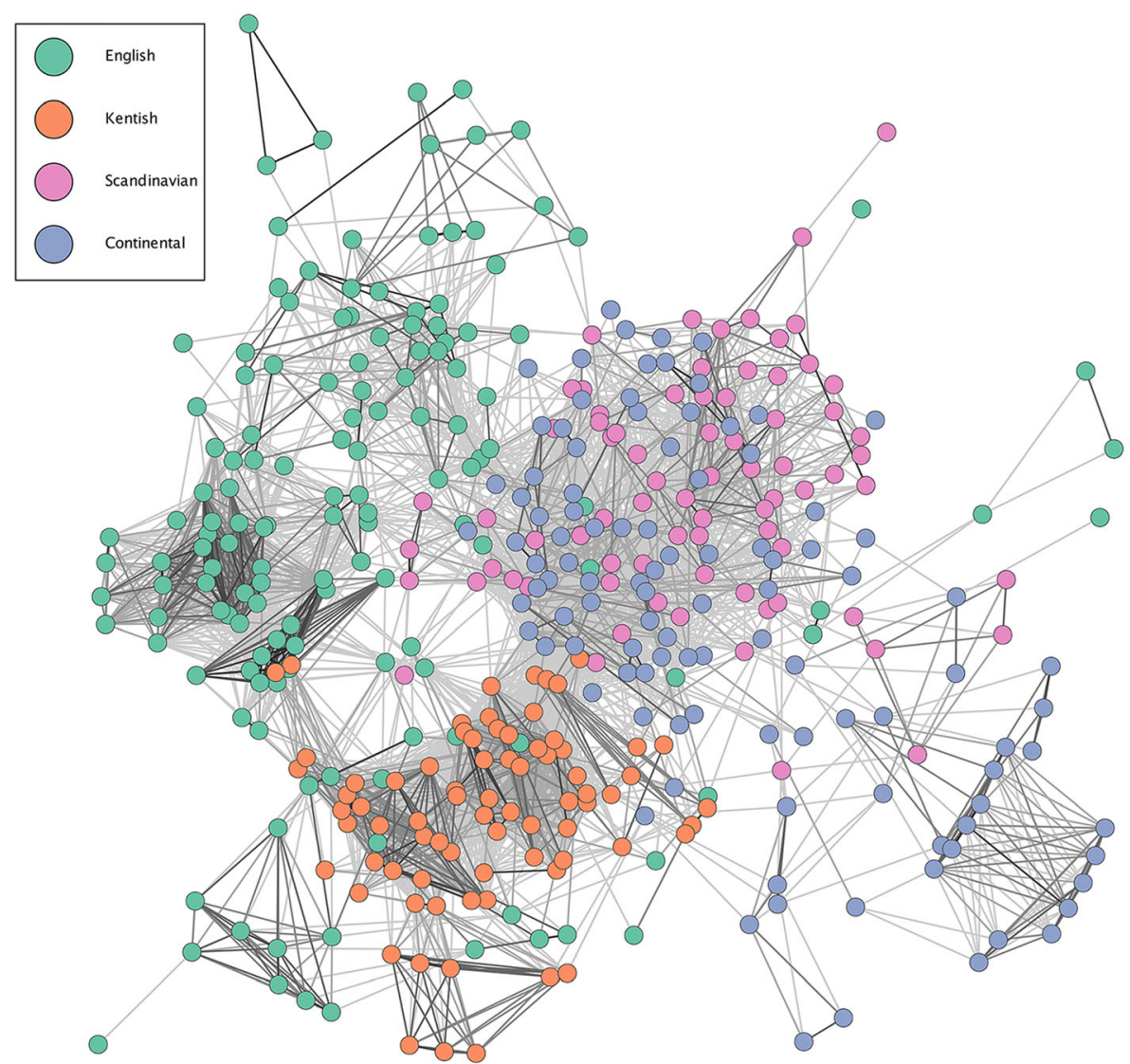

Fig. 6 Network diagram of all four series, coloured by regional type and arranged according to a backbone layout weighted by the strength of the ties, deleting those with a strength less than 3 


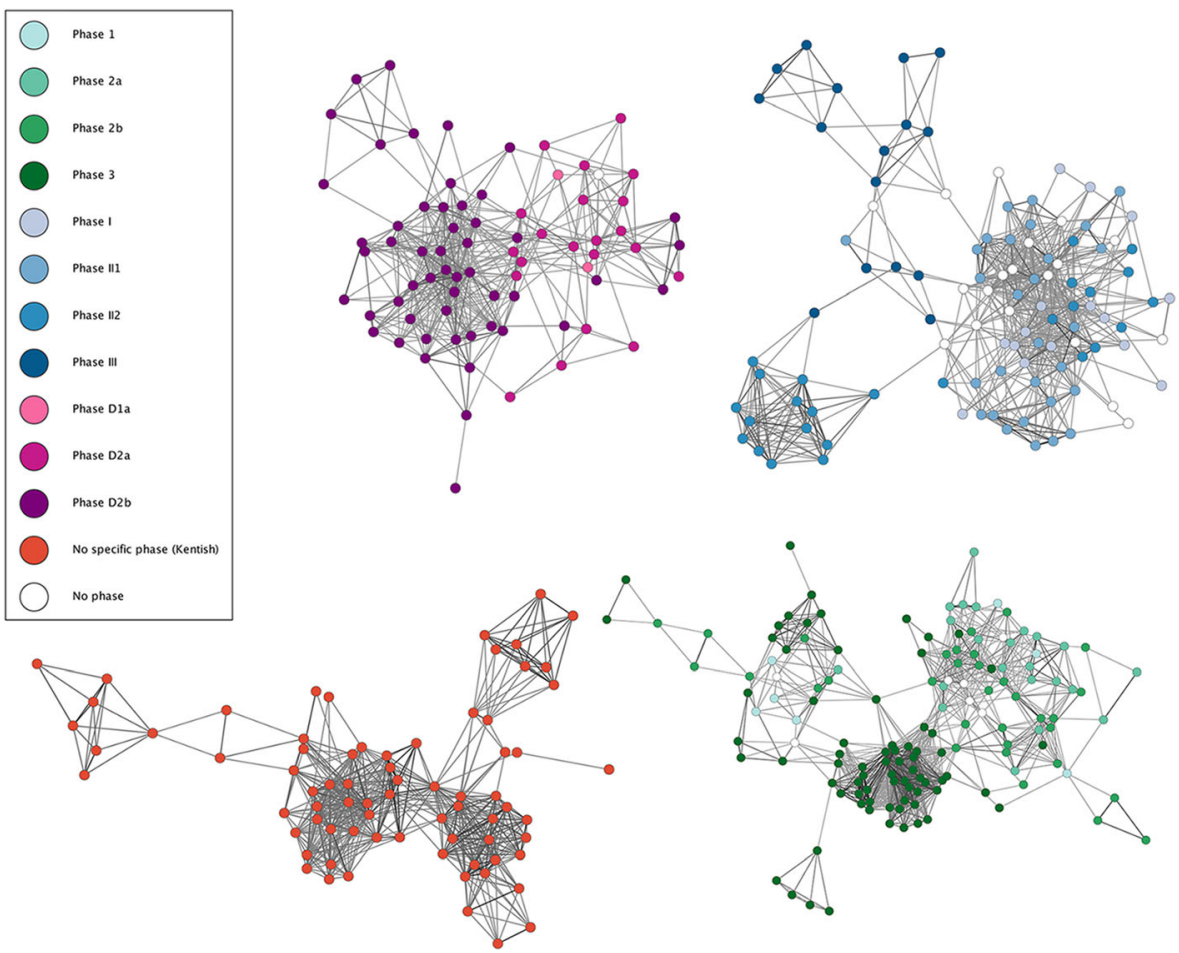

Fig. 7 Individual networks, clockwise from top left: Scandinavian; Continental; English; Kentish. All networks arranged according to as 'backbone layouts' (see Nocaj et al. 2015), weighted by the strength of the ties, deleting those with a strength less than 3, except in the case of Kent where only ties with a strength over 4 are preserved

layouts of the English, Scandinavian and Continental series retain edges of strength three and above. The Kentish series, due to the very high number of strong edges seen in Fig. 6, here retains only edges of strength four or more. These four networks show that each regional series has a very similar structure, both in terms of the overall layout, as well as its chronological patterning. The key observation is that in the English, Scandinavian and Continental groups, it is only among the latest brooches (phases 3, III and D2b respectively) that very strong edges occur between brooches, demonstrating an overall trend toward homogenisation over time. The chronological patterning of Kentish brooches remains unknown, and it may well be the case that much of the series actually falls into a single, brief, homogeneous phase. However, future investigations may well look for a later phase among the projecting limbs of the network, especially the clusters on the far left and upper right. This trend toward homogenisation over time is of interest regarding its implications for the dynamic meanings of these items and the social networks of which they were part, which will be discussed further below.

Finally, these networks can be taken out of abstract mathematical space. Figure 8 shows a map of all four series coloured by their relative chronology. There is much detail here that is of interest, but the most striking aspect is that the strongest edges are not found between highly proximal locations but over relatively distant ones. Links at a distance of up to about $600 \mathrm{~km}$ between southern England and northern and western 


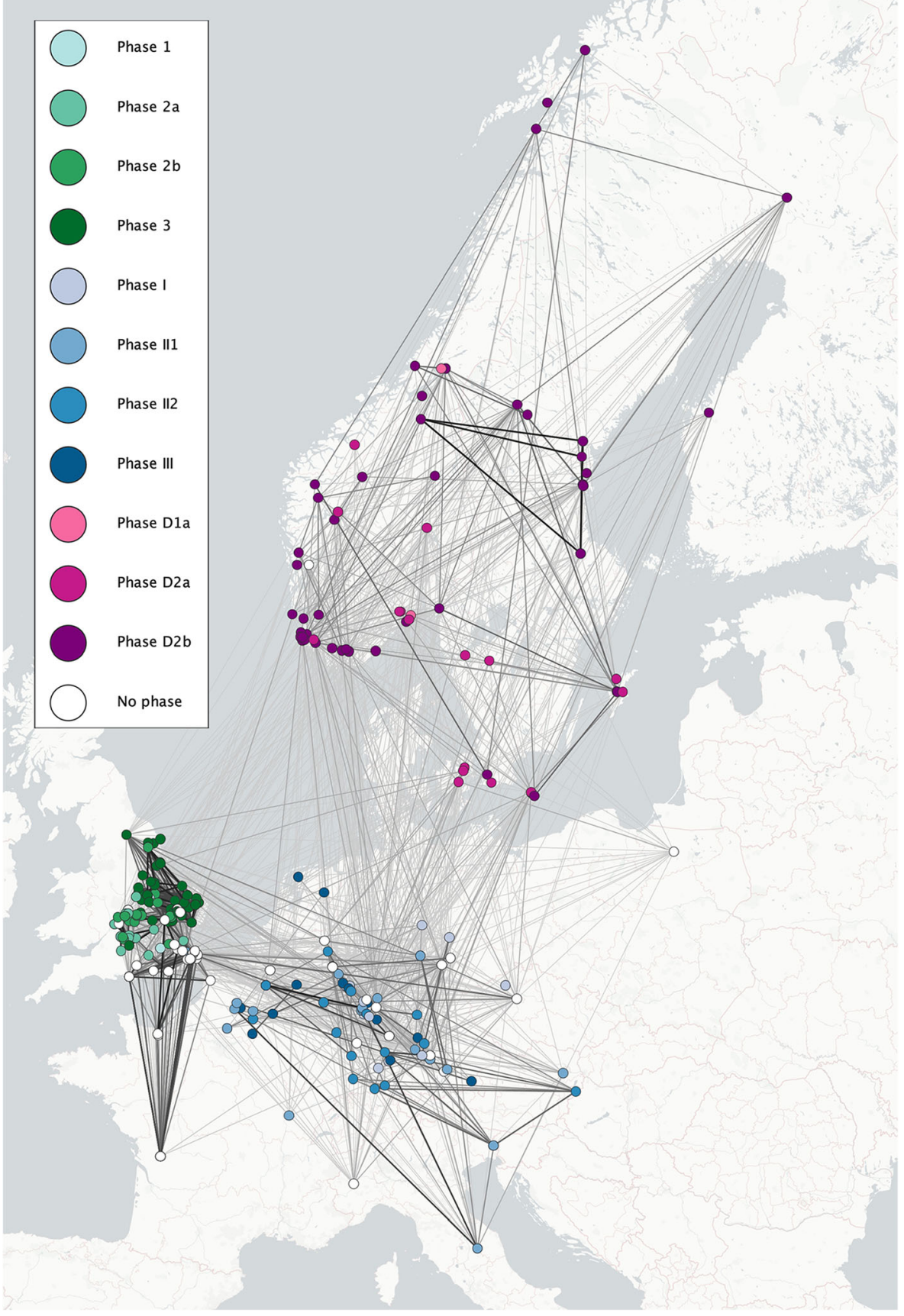

Fig. 8 Geographical layout of all square-headed brooches coloured by regional series and chronology (green $=$ English, blue $=$ Continental, purple $=$ Scandinavian, Kentish not labelled due to lack of chronological information), maintaining only ties of strength 3 or greater

France are obvious, as are the multiple strong edges running north and south and northwest to southeast in England, up to distances of about $300 \mathrm{~km}$. Greater distances, 
however, are achieved between western, central and southern Europe, such as between northeast France and Italy at a distance of about $1000 \mathrm{~km}$, or of about $700 \mathrm{~km}$ between Hungary and southwest Germany. Very strong connections of about $350 \mathrm{~km}$ appear between Bornholm and Gotland, as well up to about $550 \mathrm{~km}$ between western Norway and eastern Sweden at various points, and the 1000-km distance up and down the western Norwegian coast. Following the patterns that emerged from the individual networks of Fig. 7, it remains true that these strongest and often geographically distant connections are characteristic of the latest phases of at least the English, Continental and Scandinavian series. Working with the existing chronologies for these series, one might therefore conclude that these very close connections between faraway places were only achieved around the mid-sixth century in much of Europe, and perhaps a little earlier in the same century in Scandinavia.

\section{Conceptual Aspects of Artefact Variation: Invention, Citation, Obsolescence}

What does it mean to convert stylistic classifications into network data? These networks are not direct representations of social networks (i.e. a map of the relationships between human individuals or communities) any more than the conventional series of square-headed brooches represent four distinct social groups: a network drawn from stylistic linkages and a type series are equally abstract. Accordingly, moving from a network diagram based on stylistic variation to a social network requires us to explore the human and material processes encoded in these structures.

To understand what these networks mean at a conceptual level, it is necessary to return to the basic nature of the data: the motifs. It was theoretically posited that each motif classification was sufficiently unique to have had been created by a single act of inspired invention. From here, the same craftsperson may have made several copies, but it is highly likely that once in circulation, others would have copied their inventions, before the motif dropped out of the known repertoire through lack of citation. These three conceptsinvention, citation, obsolescence - are key to understanding the network diagrams as human as well as material processes. Reconceptualising a type series as a chain or flow of choices to invent, to cite or not to cite, while banishing the chimera of a finished, crystallised or Platonic 'type' provides an alternative to conventional classificatory models. In more plain terms, these network diagrams depict the ebb and flow of creativity and conservatism in abstract mathematical space, as well as across Cartesian space and time.

Invention, citation and obsolescence can all be characterised as methods of managing information: creating it, transferring it and allowing it to dissolve, and all three of these things are the results of human choice. 'Information' is an important concept in the wider field of network science: not only is knowledge of a certain thing, person or place frequently the basis of drawing a connection between two entities, but networks also facilitate the flow of information. It is a past network in this sense that this paper explores, and both objects and people are involved at every stage (Latour 2005, 67-71). In the networks above, people were responsible for the choices involved in the invention or citation of particular designs, but the objects themselves surely carried the information from craftsperson to craftsperson. Furthermore, the choices to cite or not to cite were informed by contextual knowledge of the objects that surrounded them: 
knowledge of who owned them, knowledge of where and when they were made (and by whom), all amounting to a sensitivity of what was and was not desirable. Memories of what objects lay in what graves may also have influenced these decisions. Translating the stylistic networks constructed above into social networks therefore enables the consideration of how both objects and people mediated information. In so doing, blurring the agencies of objects and people becomes almost inevitable.

Unfortunately, archaeologists usually have less than half of that picture: we have the objects, and only a small sample of them. In this particular case, we also lack positive information on the direction of citation. Although we have some general information about the overall chronological flow, with such a large sample, it is impossible to place every item in a directional sequence. ${ }^{5}$ Furthermore, there is no way of knowing how many acts of citation or copying lie between any two nodes, but the existence of most connections would have required many more objects and individuals to become archaeologically visible. Because we do not know the size of the original sample, and we also cannot know the direction in which the motifs travelled, each connection must be considered to be a conduit through which information could feasibly pass in either direction, and each node must be seen as a cloud of points originally more widely dispersed in time and space. ${ }^{6}$ Of course, it is conceivable that any of the long-distance connections could be flukes down to the unusual movements of specific individuals. ${ }^{7}$ However, when the patterns are repeated as they are here (e.g. stronger connections existing later in at least three of the conventional series) or repeated as well as unintuitive (e.g. stronger connections being held over longer rather than shorter distances), we can be more confident to have uncovered a genuine set of past networks that tell us something about how these dress adornments intervened in human and non-human relationships.

\section{Interpretation: Square-Headed Brooches in Fifth- to Sixth-Century Europe}

The network visualisations presented above highlight three main structural properties embedded in the variation of square-headed brooches:

1. The conventional English, Kentish, Continental and Scandinavian series can be reconceived as a single network, within which the Scandinavian and Continental series are not always easy to separate, and the English and Kentish series are highly distinctive

2. Patterns of internal stylistic variation in the four conventional series are highly comparable, with the presence of both heterogeneous and homogenous clusters,

\footnotetext{
${ }^{5}$ Many attempts have been made to determine the directionality of stylistic influence among these brooches. For the most advanced and detailed accounts of the brooches discussed here, see Haseloff (1981) and Hines (1997). Suzuki (2008) provides perhaps the most sophisticated study to date of another brooch type.

${ }^{6}$ It is also for these reasons that formal network analysis has a limited role in the present account. Investigating measures of centrality would certainly be possible (see e.g. Brughmanns 2012, 627), but the interpretation would be extremely complex. For instance, a node with high degree centrality (i.e. a high number of connecting edges) could be equally indicative of the opposite properties of high derivation and influence, but without directionality there is no way of telling.

${ }^{7}$ See, for instance, extensive discussion of a brooch from Kvåle, Norway, and its obvious links with Baltic (Kristoffersen 2000, 140-41; Røstad 2016, 173-4; 327-9)
} 
the latter being the latest development in at the least the English, Scandinavian and Continental series, and possibly also the Kentish series

3. These late and strong connections are often found over greater geographical distances than they are short ones

Some of these patterns have been previously identified, but only in particular regions and without regard to the wider European context. For instance, Hines $(1997,306)$ noted the increased homogeneity among the later English square-headed brooches, while Kristoffersen (2000, 157-66) and Røstad (2016, 220-3) have also noted similar homogenisation among various later types of Scandinavian brooches, including the square-headed and cruciform varieties. The same has also been shown for the latest English cruciform brooches that were roughly contemporary with the latest square-headed brooches (Martin 2015, 64-70). Homogenisation (i.e. diminished invention and increased citation) therefore appears to have been a generalised European phenomenon for multiple classes of object during the sixth century, just before all these brooch forms became obsolete.

As early as 1941, Nissen Fett remarked upon the surprisingly long-distance connections between the Continental square-headed brooches in a brief discussion about their general lack of regional characteristics, commenting that in this respect, they differed from the Scandinavian series (Nissen Fett 1941, 60), which indeed appear to have stronger regional tendencies (e.g. Røstad 2016, 298-310). Kristoffersen, however, has also remarked upon the long-distance connections found between some closely related brooches of the Scandinavian series between Rogaland, Sognefjord and Oslofjord (Kristoffersen 1999, 166-7), some equivalent to those observed above. The offered explanation was that of a consolidated and increasingly distinctive regional Jæren style typical of southwest Norway, limited to that region in the earliest phases, but expanding far beyond it in the sixth century as a sign of the region's political ascendency, and the potential role of the women that wore these brooches in exogamous marriage alliances (Kristoffersen 2000, 139-42, 168-71). Røstad (2016, 414-23) has since elaborated on these ideas by suggesting that women who moved between communities in this manner retained their brooches, displaying their specific ethnic identities as foreigners in their new communities.

Hines $(1997,308)$ has also shown that the very latest items in the English series pushed further north than the earlier items, just as the Scandinavian series did. Meanwhile, the English cruciform brooches mentioned above similarly dissolved their previous regional distributions into longer distance connections in the middle sixth century (Martin 2015, 185-9). ${ }^{8}$ Further afield, Curta's work on some of the so-called 'Slavic' brooches of Eastern Europe produced the same results, although these items were probably a little later, dating to the later sixth and seventh centuries. Curta used a 'nearest neighbour' analysis of precisely the same kind of motifs to show the predominance of long-distance relationships between the Carpathian Basin and the Middle Dnieper/southwest Ukraine, as well as over the greater distance to Masuria (Curta 2008, 53; 2010, 150; 2011, 66). The relatively late development of long-distance connections and increased homogeneity revealed by the network analyses are therefore partially replicated in previous work, and they also appear to have been part of a much wider pattern of changes seen across Europe.

\footnotetext{
${ }^{8}$ This similarity between the English cruciform and square-headed brooches relates to the fact that around the middle sixth century, the series appear to merge, again undermining the conventionally received typologies.
} 
Our chronologies have sufficient resolution to be confident that from Artic Norway to the Mediterranean, and from the North to the Black Sea, it was the sixth century that was the period in which homogenisation and long-distance connections increased. More tentatively, they suggest that this happened initially in Scandinavia during the first half of the sixth century, then in Britain and on the Continent around the mid-sixth century, and finally in eastern Europe during the later sixth century where it continued into the seventh. Although it is feasible that this took place all over Europe simultaneously, further research is needed to properly interrelate presently disjointed regional chronologies. However, even if these changes were not entirely concurrent, they certainly overlapped, and it is remarkable that they occurred across such a large area in such an analogical manner.

Nissen Fett (1941, 60) explained the long-distance connections evident in the Continental series by the breakdown of communities along the Rhine and Danube and their dispersal by processes linked to the end of the Western Empire. Indeed, this period is known as the 'Migration Period' for a reason, and although there is little doubt there were substantial migrations and disruptions in Europe in the fifth and sixth centuries, none of the strongly linked nodes in Fig. 8 correspond to any historically recorded migration, regardless of how sceptical we may be of their grounding in reality (Geary 2002; Goffart 2006). It is also true that none of the regional series of squareheaded brooches (Fig. 2) correspond to any historically posited tribal territory or early kingdom, no matter how far we might stretch the possibilities. Moreover, graves containing square-headed brooches are always a minority in a cemetery, to the point where few sites yield more than one grave containing such items. These characteristics have led to a tendency in scholarship on the square-headed brooches of Europe to focus instead on the geographical dispersal of stylistic influence to fill an art-historical narrative, a pursuit to which considerable importance has been attached since Salin (1904) showed that these items were likely to be the primary vehicles by which Salin's Style I was disseminated.

Hines is one of few scholars to have addressed the homogenisation event in England, characterising it as a 'concentration of the direction of productive effort', among a series of dress ornaments that were worn to display status among the wealthiest families, being generally found in only the richest grave assemblages (Hines 1997, 301, 308-9). Similar conclusions have been reached for the latest cruciform brooches, suggesting that their homogenisation and long-distance connectivity were part of the consolidation of elites involved in the foundation of early kingdoms (Martin 2015, 185-9). As such, the latest examples of squareheaded brooches may well have been part of a more long-term pattern of the more restricted and consolidated elites that become starkly visible in the extraordinarily wealthy and monumental burials of the later sixth and seventh centuries in England and eastern Sweden (Hines 1997, 309). In this sense, these brooches may have become increasingly emblematic of an elevated class of individual, so that the symbol became more standardised, recognisable and homogenous. Røstad (2016, 337-40) has come to the same conclusions for the homogenisation of relief brooches in Scandinavia, interpreting these items as symbols of an ethnic or cultural identity that became more emblematic during the earlier sixth century, indicative of a social structure that was becoming more rigid and less negotiable. In the later 6th and 7th centuries, Scandinavia was the only place in which square- 
headed brooches continued to be made, albeit in a slightly different form (see Olsen 2006). Fascinatingly, Røstad (2018, 96-8) identifies in the very initial stages of this later transformation a period of high creativity and heterogeneity, providing a window into the potentially perpetual cycles of innovation and conservatism through which material cultural forms can pass.

These interpretations, in which brooches were made in intentionally more rigid and emblematic forms in order to express an increasingly rigid social structure, can be slightly adjusted through a more nuanced theoretical consideration of the relationship between objects and power. Power can be thought of as an asymmetry between agents resulting from action or bodily performance, such as an act of violence, humiliation, honour, generosity, obligation and so on. The only way of sustaining the asymmetry beyond that momentary performance is by using material culture (Latour 2005, 64-71). This could be as blatant as a razor wire fence or a colonial plantation, or as subtle as, for instance, a mode of dress or personal ornamentation. Indeed, different modes of dress cannot help but influence social behaviours, and it is perhaps these properties that motivated the sixth-century adaptations in flows of citation and invention, with a concentration on the former rather than the latter. Despite much speculation on the matter, we cannot presently determine precisely what actions transported this information in the form of brooches: itinerant craftspeople, face-to-face gift exchange or patrilocal marriage exchanges are all possibilities, but possibilities without demonstrable supporting evidence. Nevertheless, we can say with certainty that there is no such thing as an abstract 'social connection'. Such connections have no essence beyond their bodily performance unless they are constituted by physical objects. In this sense, however, they may have moved, these brooches were not expressions or symbols of connection: they were the connections. The homogenisation and extended connections observed in the sixth century therefore do not symbolise the growth of links between more consolidated elites: they actually constituted those links. In so doing, square-headed brooches created the idea of an extended elite community that went far beyond the locality in which an individual lived. It was this asymmetry-i.e. the connection or lack of connection with a faraway placethat seems to have become especially important to some individuals throughout Europe during the sixth century.

Van Oyen (2016c) has interpreted a similar tendency in the terra sigillata pottery produced in Roman Gaul, suggesting that stylistic relationships can be characterised as 'relational constellations', which are essentially more abstract versions of the networks explored here. Such constellations can be 'fluid' or 'categorical'. 'Fluid constellations' are characterised by creativity and invention, producing heterogeneous sets of objects. 'Categorical constellations' are characterised by rigidity and conservatism, leading to homogeneous types. Because homogeneity presupposes a commonly regarded set of principles to which objects can subscribe to a greater or lesser extent, the artistry of any such item can be immediately judged, so that categorical constellations create the potential for increased internal competition (Van Oyen 2016c, 368). In these terms, across sixth-century Europe, square-headed brooches switched from fluid to categorical constellations, producing not only the potential for competition between those with and without such items, but also signalling elements of internal competition between wearers of more easily compared jewellery. 


\section{Summary}

Many questions remain unanswered, perhaps foremost among them the mechanisms by which these brooches actually moved, and by which information flowed through this network. There is also a substantial question concerning the network structures of other groups of contemporary brooches. The square-headed brooches are among the largest and most elaborate objects of personal ornamentation of the fifth and sixth centuries, and although a small number of other series have been mentioned, there are many other types that may well not show the same kinds of long-distance connections. There are also questions about the roles of women in these mechanisms, given that it is almost exclusively women that wore these items. These questions have been addressed elsewhere (Kristoffersen 2000; Martin 2015; Røstad 2016), but the role of women in long-distance networks requires more consideration.

Nevertheless, the principal aim of this paper was to show that a change in method can alter the kinds of questions certain artefacts provoke. The set of artefacts used to demonstrate this - the square-headed brooches of Europe - are particularly entrenched in conventional typological methods, which have to date provoked questions largely to do with group identity and stylistic influence; the latter being an extension of the former insofar as the interest has been in who had influence over whom. The playful experiments with network methods explored in this paper not only provoke different theoretical questions about the processes behind artefact variation, but they also prompt alternative interpretations based on the flow of information, and the asymmetries or differential power structures this creates, as opposed to the efforts of groups to maintain their boundaries and overwhelm those of others with material symbols. In terms of information flow, this paper asks why certain regions and phases witnessed more or less citation as opposed to invention, offering one possible explanation based on the idea that square-headed brooches were vital cogs in the creation of long-distance networks. It was this property that intensified through the sixth century in Western Europe, and possibly slightly later in Eastern Europe, as people became increasingly intent on creating and maintaining these links with specific and shared modes of dress. Moreover, the homogenisation of some varieties of brooches in this period may have facilitated direct comparisons, creating the potential for increased levels of competition within these long-distance networks.

The secondary aim of this paper was to demonstrate the opportunities that broader scale approaches can afford. Work in early medieval archaeology is typically regional, and as specialist knowledge of artefact types has increased, the tendency has been to become ever more local. With this otherwise highly beneficial work, however, comes the risk of losing the big picture, and these four series of square-headed brooches, despite their obvious relationships, have not been examined in any detail side by side since the early twentieth century (Salin 1904). Although it is partly our much increased sample sizes that have made broad scale work less feasible since this time, part of the limitation has been methodological. Network approaches offer just one possible alternative capable of visualising archaeological material and interpretation on a much larger scale.

Acknowledgements This paper was developed during a postdoctoral fellowship at the University of Oxford's School of Archaeology funded by the British Academy. Versions of the paper were presented at the European Association of Archaeologist's meeting in Glasgow, and at research seminars at the University of 
Stockholm's Department of Archaeology and Classical Studies, the Römisch-Germanisches Zentralmuseum in Mainz, and the UCL Institute of Archaeology and British Museum joint medieval seminar series. Many thanks are due to the organisers of these events for their kind invitations, and to all the helpful comments that were made following the presentations, all of which have helped to form this paper. Especial thanks are due to Angus Mol for initial practical instruction on the use of network methods. I also thank the three anonymous peer reviewers whose comments enriched and improved this paper. Although this paper is the product of a number of conversations and presentations with and among colleagues, any errors or shortcomings remain my own.

Open Access This article is licensed under a Creative Commons Attribution 4.0 International License, which permits use, sharing, adaptation, distribution and reproduction in any medium or format, as long as you give appropriate credit to the original author(s) and the source, provide a link to the Creative Commons licence, and indicate if changes were made. The images or other third party material in this article are included in the article's Creative Commons licence, unless indicated otherwise in a credit line to the material. If material is not included in the article's Creative Commons licence and your intended use is not permitted by statutory regulation or exceeds the permitted use, you will need to obtain permission directly from the copyright holder. To view a copy of this licence, visit http://creativecommons.org/licenses/by/4.0/.

\section{References}

Adams, W. Y., \& Adams, E. W. (1991). Archaeological typology and practical reality. Cambridge: Cambridge University Press.

Bakka, E. (1973). Goldbrakteaten in norwegischen Grabfunden. Frümittelalterliche Studien, 7, 53-87.

Brughmans, T. (2012). Thinking through networks: a review of formal network methods in archaeology. Journal of Archaeological Method and Theory, 20, 623-662.

Collar, A., Coward, F., Brughmans, T., \& Mills, B. J. (2015). Networks in archaeology: phenomena, abstraction, representation. Journal of Archaeological Method and Theory, 22(1), 1-32.

Coole, D. H., \& Frost, S. (Eds.). (2010). New materialisms: ontology, agency, and politics. Durham: Duke University Press.

Curta, F. (2006). Slavic bow fibulae? Werner's class I D revisited. Acta Archaeologica Academiae Hungaricae, 57, 423-474.

Curta, F. (2008). Some remarks on the bow fibulae of Werner's class I C. Slavia Antiqua, 49, 45-98.

Curta, F. (2010). Not "Slavic” after all: bow fibulae of Werner’s Class II A. In A. Măgureanu \& E. Gáll (Eds.), Între stepă şi imperiu: studii în onoarea lui Radu Harhoiu (pp. 149-175). Bucharest: Rennaissance.

Curta, F. (2011). Werner's class I C: erratum corrigendum cum commentariis. Ephemeris Napocensis, 21, 63110 .

Deleuze, G., \& Guattari, F. (1987). A thousand plateaus: capitalism and schizophrenia. Minneapolis: University of Minnesota Press.

Dickinson, T. M. (1991). Material culture as social expression: the case of Saxon saucer brooches with running spiral decoration. Studien zur Sachsenforschung, 7, 39-70.

Effros, B. (2004). Dressing conservatively: women's brooches as markers of ethnic identity? In L. Brubaker \& J. M. H. Smith (Eds.), Gender in the early medieval world: east and west, 300-900 (pp. 165-184). Cambridge: Cambridge University Press.

Fredriksen, P. D., Kristoffersen, E. S., \& Zimmermann, U. (2014). Innovation and collapse: bucket-shaped pottery and metalwork in the terminal migration period. Norwegian Archaeological Review, 47, 1-22.

Fuchs, S., \& Werner, J. (1950). Die langobardischen Fibeln aus Italien. Berlin: Gebr. Mann.

Gauß, F. (2009). Völkerwanderungszeitliche "Blechfibeln": typologie, chronologie, interpretation. Berlin: Walter de Gruyter.

Geary, P. (2002). The myth of nations: the medieval origins of Europe. Princeton and Oxford: Princeton University Press.

Goffart, W. (2006). Barbarian tides: the migration age and the later Roman Empire. Philadelphia: University of Pennsylvania Press.

Gosden, C., \& Malafouris, L. (2015). Process archaeology (P-Arch). World Archaeology, 28, 1-17.

Hakenbeck, S. E. (2007). Situational ethnicity and nested identities: new approaches to an old problem. AngloSaxon Studies in Archaeology and History, 14, 19-27. 
Halsall, G. (2010). Cemeteries and society in Merovingian Gaul: selected studies in history and archaeology, 1992-2009. Leiden: Brill.

Haseloff, G. (1981). Die Germanische Tierornamentik der Völkerwanderungszeit: Studien zu Salin's Styl I. Berlin: De Gruyter.

Hines, J. (1997). A new corpus of Anglo-Saxon great square-headed brooches. Woodbridge: Boydell Press.

Holmes, C., \& Standen, N. (2018). Introduction: towards a global middle ages. Past and Present, 238(Supplement 13), 1-44.

Ingold, T. (2012). Toward an ecology of materials. Annual Review of Anthropology, 41(1), 427-442.

Koch, A. (1998). Bügelfibeln der Merowingerzeit im westlichen Frankenreich. Mainz: RömischGermanisches Zentralmuseum.

Kristoffersen, E. S. (1999). Migration period chronology in Norway. In J. Hines, K. Høilund Nielsen, \& F. Siegmund (Eds.), The pace of change: studies in early medieval chronology (pp. 93-114). Oxford: Oxbow.

Kristoffersen, E. S. (2000). Sverd og Spenne: Dyreornamentikk og Sosial Kontekst. Bergen: Høyskole Forlaget.

Kristoffersen, E. S. (2004). Symbolism in rites of transition in Iron Age Norway. In Selected papers and discussions from the Tenth Anniversary Symposion of the Norwegian Institute at Athens, 12-16 May 1999 (pp. 287-303). Athens: The Norwegian Institute at Athens.

Kristoffersen, E. S., \& Magnus, B. (2010). Spannformete kar Utvikling og variasjon. Stavanger: Arkeologisk museum, Universitetet i Stavanger.

Kühn, H. (1965). Die Germanischen Bügelfibeln der Völkerwanderungszeit in der Rheinprovinz. Graz: Akademische Druck- u. Verlagsanstalt.

Kühn, H. (1974). Die Germanischen Bügelfibeln der Völkeranderungszeit in Süddeutschland. Graz: Akedemische Druck- u. Verlagsanstalt.

Latour, B. (2005). Reassembling the social: an introduction to actor-network-theory. Oxford: Oxford University Press.

Leigh, D. (1980). The square-headed brooches of sixth-century Kent. PhD thesis, University of Cardiff. https://ethos.bl.uk/OrderDetails.do?uin=uk.bl.ethos.276763. Accessed 10 June 2019.

Martin, T. F. (2015). The cruciform brooch and Anglo-Saxon England. Woodbridge: Boydell and Brewer.

Martin, T. F. (2019). A matter of scale: some impediments to broad archaeological perspectives on postRoman European bow brooches. In A. Cieśliński \& B. Kontny (Eds.), Interacting barbarians contacts, exchange and migrations in the first millennium $A D$ (pp. 139-146). Braunschweig: Braunschweigischen Landesmuseum.

Mills, B. J. (2017). Social network analysis in archaeology. Annual Review of Anthropology, 46, 379-397.

Mol, A. A. A. (2007). Costly giving, giving guaizas: Towards an organic model of the exchange of social valuables in the late Ceramic Age Caribbean. Leiden: Sidestone Press.

Neumeister, P. (2014). The ancient Thuringians - problems of names and family connections. In J. FriesKnoblach \& H. Steuer (Eds.), The Baiuvarii and Thuringi: an ethnographic perspective (pp. 83-101). Woodbridge: Boydell and Brewer.

Nissen Fett, E. (1941). Relief-fibeln von nordischem Typus in Mitteleuropa. Bergen: Bergens Museum.

Nissen Meyer, E. (1934). Relieffspenner i Norden. Aarborg: Bergens Museum.

Nocaj, A., Ortmann, M., \& Brandes, U. (2015). Untangling the hairballs of multi-centered, small-world online social media networks. Journal of Graph Algorithms and Applications, 19(2), 595-618.

Olsen, V. S. (2006). The development of (proto)-disc-on-bow brooches in England, Frisia and Scandinavia. Palaeohistoria, 47/48, 479-528.

Parfitt, K., \& Anderson, T. (2012). Buckland Anglo-Saxon cemetery, Dover: excavations 1994. Canterbury: Canterbury Archaeological Trust.

Parfitt, K., \& Brugmann, B. (1997). The Anglo-Saxon cemetery on Mill Hill, Deal, Kent. London: The Society for Medieval Archaeology.

Pedersen, U., \& Kristoffersen, E. (2018). A Scandinavian relief brooch: artistic vision and practical method combined. Medieval Archaeology, 62(2), 219-236.

Pohl, W. (2002). Ethnicity, theory and tradition: a response. In A. Gillett (Ed.), On barbarian identity: critical approaches to ethnicity in the early Middle Ages (pp. 221-239). Turnhout: Brepols.

Røstad, I. M. (2016). Smykkenes språk: smykker og identitetsforhandlinger i Skandinavia ca. 400-650/700 e.Kr. Unpublished PhD thesis, Universitetet i Oslo.

Røstad, I. M. (2018). The immortal brooch. In M. Vedeler, I. M. Røstad, E. S. Kristoffersen, \& Z. T. Glørstad (Eds.), Charismatic objects: from Roman times to the Middle Ages (pp. 73-101). Oslo: Cappelen Damm As. 
Salin, B. (1904). Die Altgermanische Thierornamentik: Typologische Studie über germanische Metallgegenstände aus dem IV. bis IX. Jahrhundert, nebst einer studie über irische Ornamentik. Stockholm: K. L. Beckmans Buchdruckerei.

Sjøvold, T. (1993). The Scandinavian relief brooches of the migration period. Oslo: Institutt for arkeologi, kunsthistorie og numismatikk oldsaksamlingen.

Stoodley, N. (1999). The spindle and the spear. A critical enquiry into the construction and meaning of gender in the early Anglo-Saxon burial rite. Oxford: British Archaeological Reports.

Straume, E. (1987). Gläser mit Facettenschliff aus skandinavischen Gräbern des 4. und 5. Jahrhunderts $n$. Chr. Oslo: Oslo Universitetsforlaget.

Suzuki, S. (2008). Anglo-Saxon button brooches: Typology, geneaology, chronology. Woodbridge: Boydell Press.

Theune, C. (2014). Signs and symbols in archaeological material finds. In J. Fries-Knoblach \& H. Steuer (Eds.), The Baiuvarii and Thuringi: an ethnographic perspective (pp. 271-288). Woodbridge: Boydell and Brewer.

Thomas, J. (2015). The future of archaeological theory. Antiquity, 89(348), 1287-1296.

Van Oyen, A. (2012). Knowledge systems in the production of terra sigillata: moving beyond the local/global paradox. In E. Duggan (Ed.), TRAC 2011: Proceedings of the Twenty First Theoretical Roman Archaeology Conference, Newcastle 2011 (pp. 48-59). Oxford: Oxbow Books.

Van Oyen, A. (2013). Towards a post-colonial artefact analysis. Archaeological Dialogues, 20(1), 81-107. https://doi.org/10.1017/S1380203813000123.

Van Oyen, A. (2015). Actor-network theory's take on archaeological types: becoming, material agency and historical explanation. Cambridge Archaeological Journal, 25(1), 63-78.

Van Oyen, A. (2016a). Networks or work-nets? Actor-network theory and multiple social topologies in the production of Roman terra sigillata. In T. Brughmans, A. Collar, \& F. Coward (Eds.), The connected past: Network studies in archaeology and history (pp. 35-56). Oxford: Oxford University Press.

Van Oyen, A. (2016b). How things make history: the Roman Empire and its terra sigillata pottery. Amsterdam: Amsterdam University Press.

Van Oyen, A. (2016c). Historicising material agency: from relations to relational constellations. Journal of Archaeological Method and Theory, 23, 354-378.

Wenskus, R. (1961). Stammesbildung und Verfassung: das werden der frühmittelalterlichen Gentes. Cologne: Böhlau.

Werner, J. (1950). Slawische Bügelfibeln des 7. Jahrhunderts. In G. Behrens (Ed.), Reinecke Festschrift zum 75. Geburtstag von Paul Reinecke am 25. September 1947 (pp. 155-172). Mainz: E. Schneider.

Publisher's Note Springer Nature remains neutral with regard to jurisdictional claims in published maps and institutional affiliations. 